\title{
A new raninoid crab (Decapoda, Brachyura, Raninidae) from the early Oligocene (late Rupelian) of Italy
}

\author{
Giovanni Pasini ${ }^{1}$, Alessandro Garassino ${ }^{2 *}$
}

\begin{abstract}
Pasini \& Garassino (2017) did a preliminary systematic review of the worldwide fossil species of Ranina, pointing out that it was used as "basket genus" for almost two centuries to accommodate different questionable taxa pertaining or not to Raninoidea. The result was that just four species were possibly assigned to Ranina compared to 23 species previously listed by Karasawa et al. (2014). Among the studied species, a rich sample of specimens from the early Oligocene of the Ligure-Piemontese Basin (Italy), previously assigned to Ranina speciosa by Ristori (1889) and Allasinaz (1987), has been revised and here discussed. The studied specimens are herein assigned to the new genus Alcespina, with A. ovadaensis n. sp (Raninidae), whereas five specimens of Allasinaz's original sample are assigned to Raninoides H. Milne Edwards, 1837. Finally, this study allows us to review the questionable species Ranina berglundi Squires \& Demetrion, 1992, from the early Eocene of Mexico, herein also assigned to A. berglundi (Squires \& Demetrion, 1992) n. comb.
\end{abstract} Italy.

Key words: Decapoda, Brachyura, Raninindae, Oligocene, NW

Riassunto - Un nuovo raninoide (Decapoda, Brachyura, Raninidae) dell'Oligocene inferiore (Rupeliano superiore) d'Italia.

Pasini e Garassino (2017), hanno effettuato una preliminare revisione sistematica delle specie fossili mondiali attribuite a Ranina, evidenziando come il genere sia stato usato per almeno due secoli come un "contenitore" nel quale raccogliere discutibili taxa appartenenti, e non, alla superfamiglia Raninoidea. Risultato della revisione è stato quello di ridurre a sole quattro le specie possibilmente attribuibili a Ranina, rispetto alle 23 precedentemente elencate da Karasawa et al. (2014). Fra le specie attribuite a Ranina, un ampio campione di esemplari provenienti dall'Oligocene inferiore del bacino Ligure-Piemontese, precedentemente attribuiti a Ranina speciosa da Ristori (1889) e Allasinaz (1987), è stato qui riesaminato e discusso. I campioni studiati sono stati assegnati al nuovo genere Alcespina con A. ovadaensis n. sp (Raninidae), mentre cinque esemplari del campione originale di Allasinaz (1987) sono stati attribuiti a Raninoides H. Milne Edwards, 1837. Inoltre il presente studio ha permesso di revisionare anche la dubbia specie

\footnotetext{
${ }^{1}$ Via Alessandro Volta 16, 22070 Appiano Gentile (CO), Italia. E-mail: juanaldopasini@tiscali.it

2 Sezione di Paleontologia degli Invertebrati, Museo di Storia Naturale, Corso Venezia 55, 20121 Milano, Italia.

* Corresponding author: alessandro.garassino@comune.milano.it; alegarassino@gmail.com
}

(C) 2017 Giovanni Pasini, Alessandro Garassino

Received: 16 November 2016

Accepted for publication: 2 March 2017
Ranina berglundi Squires \& Demetrion, 1992, dell'Eocene inferiore del Messico, che è stata a sua volta assegnata a $A$. berglundi (Squires \& Demetrion, 1992) n. comb.

Parole chiave: Decapoda, Brachyura, Raninidae, Oligocene, Italia nord-occidentale.

\section{INTRODUCTION}

Ristori (1889) and Allasinaz (1987) reported some well-preserved specimens from several localities of the early Oligocene Ligure-Piemontese Basin (NW Italy) assigning them to Ranina (Ranina) speciosa (von Münster, 1840). Later De Angeli \& Beschin (2011: 16) discussed the assignment, pointing out that the specimens had more close affinities with $R$. bouilleana A. Milne Edwards, 1872.

Recently, Pasini \& Garassino (2017) considered $R$. bouilleana and $R$. speciosa as questionable Ranina species, since the type material of both species does not preserve enough diagnostic characters for a specific systematic assignment.

Indeed a close review of the original sample by Allasinaz (1987) including carapaces, some pleonal parts, and thoracic appendages allows us to assign the studied specimens to Alcespina n. gen., with $A$. ovadaensis n. gen., n. sp. (Raninidae), based upon diagnostic fossil characters ('proxy characters', sensu Schweitzer, 2003) detected and here discussed, whereas five smaller specimens considered by Allasinaz (1987: 533, Pl. 1, figs. 12-16), as molting carapace of juvenile individuals of Ranina (Ranina) speciosa, have instead been ascribed to Raninoides cf. $R$. pliocenicus De Angeli, Garassino \& Pasini, 2009. Finally, this study allows a review of the systematics of the questionable species Ranina berglundi Squires \& Demetrion, 1992, from the early Eocene of Mexico, herein ascribed to Alcespina berglundi (Squires \& Demetrion, 1992) n. comb.

\section{MATERIALS AND METHODS}

The studied specimens were collected at several localities located behind the Bormida and Stura Rivers (Cassinelle, Ciglione, Ponzone, Rio Volpina, Alessandria, southern Piedmont, NW Italy) (Fig. 1) and Giusvalla (Savona, Liguria, NW Italy), along the Ligure Piemontese Basin, from transitional sandy-marl layers pertaining to the upper Molare Formation, to the Rigoroso Marl, both ascribed to 


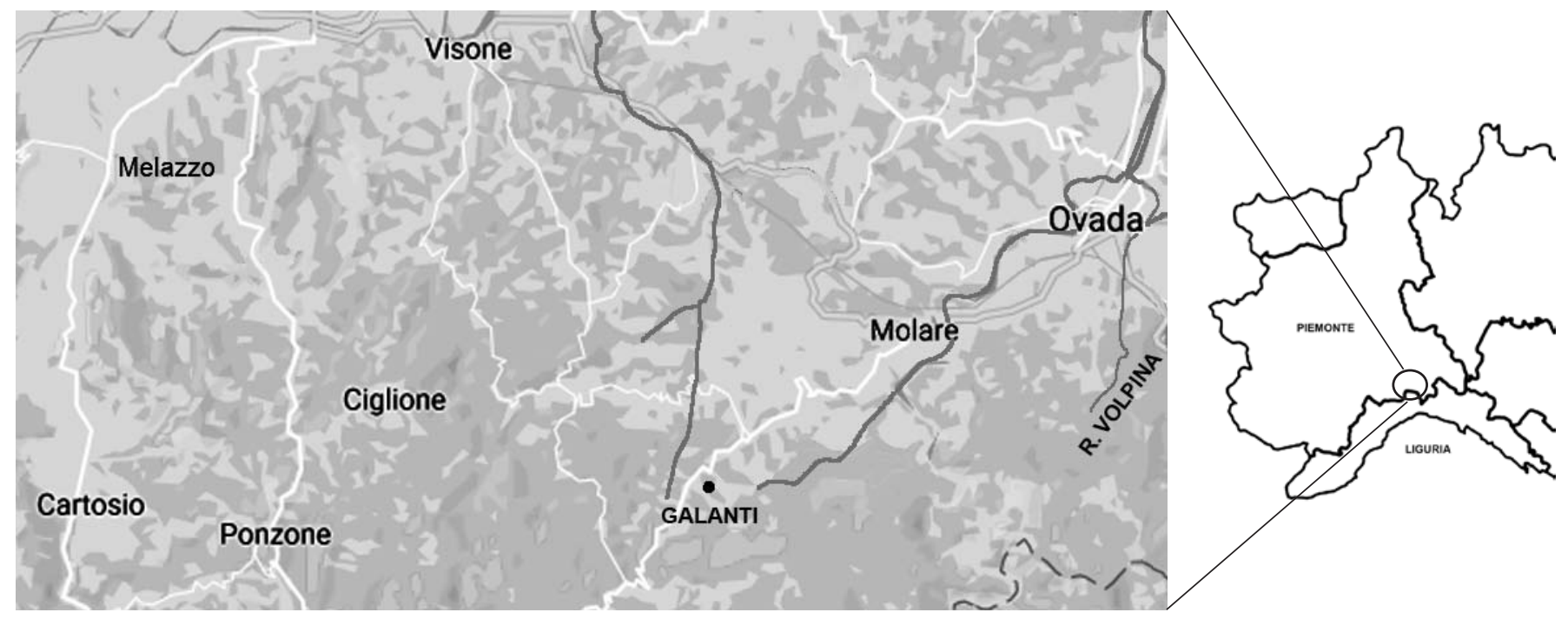

Fig. 1 - Map of studied area depicting main fossiliferous localities in Alessandria province. (after Allasinaz, 1987).

the late Rupelian (early Oligocene) (for full references see Allasinaz, 1987: 513). These sediments were deposited at the bottom of a shallow marine coastal environment, including copious invertebrate fossils of nummulites, bryozoans, mollusks, echinoderms, terrestrial plant remains, and a few different fossil crabs (for full list see: Allasinaz, 1987). The studied sample includes 23 selected specimens of the original 36 examined (MPOM 4, 5, 10, 11, 13, 20, $21,23,39,171,288,290,701,1770,1776,1779,1780$, C1, C3, RMT, 17MT, 137M, 139M), housed in the collections of the Museo Paleontologico "G. Maini", Ovada (Alessandria) (MPOM).

Remarks. All specimens of Alcespina ovadaensis n. gen., n. sp. were preserved within sub-nodular sandy hardened concretions, found in association with the fossil crabs, Coeloma vigil A. Milne Edwards, 1865 and scarce portunoid crabs (P. Damarco pers. comm., 2016). The specimens herein assigned to Raninoides $\mathrm{cf}$. $R$. pliocenicus De Angeli, Garassino \& Pasini, 2009, were collected only from the Rigoroso Marl layers, revealing a different depositional environment and possible different habitat both for Alcespina and Raninoides.

Abbreviations. Ctw: carapace total wide (including anterolateral spines); Ctl: carapace total length (including rostrum); IGM: Coleción Nacional de Paleontología, Mexico; MHN-UABCS: Museo de Historia Natural, Universidad Autónoma de Baja California Sur (Mexico); MNHM: Muséum national d'Histoire naturelle, Paris (France); MPOM: Museo Paleontologico"G. Maini", Ovada, Alessandria (Italy); s1-s6: somite1 to somite 6.

\section{SYSTEMATIC PALEONTOLOGY}

Infraorder Brachyura Latreille, 1802

Section Raninoida Ahyong, Lai, Sharkey, Colgan \& Ng, 2007

Superfamily Raninoidea De Haan, 1839

Family Raninidae De Haan, 1839

Subfamily Ranininae De Haan, 1839
Included genera - Alcespina nov. (present study); Lophoranina Fabiani, 1910; Lophoraninella Glaessner, 1936; Ranina Lamarck, 1801; Raninella A. Milne Edwards, 1862; Remyranina Schweitzer \& Feldmann, 2010; Vegaranina Van Bakel, Guinot, Artal, Fraaije \& Jagt, 2012.

\section{Genus Alcespina nov.}

Diagnosis: carapace ovate, wide fronto-orbital margin convex; trifid pointed rostrum, depressed medially; first anterolateral spine bifid, forward directed, parallel to the middle longitudinal axis; second wide anterolateral spine pointed, flat, strongly outward directed, forming by the straight upper margin, an angle around $90^{\circ}$ to the carapace middle line, with triangular unequal serrate spines (3-4) on the upper margin; dorsal regions indistinct.

Type species: Alcespina ovadaensis $\mathrm{n}$. $\mathrm{sp}$.

Included fossil species: Alcespina berglundi (Squires \& Demetrion, 1992) n. comb. (this paper).

Etymology: from Alces (elk), and spina (spine), alluding to the second anterolateral spines shape, remembering elk horns.

Geological range: early Eocene - early Oligocene.

Palaeogeographic distribution: the genus is reported from the NE Pacific [Alcespina berglundi (Squires \& Demetrion, 1992) n. comb.] and Mediterranean area $(A$. ovadensis $\mathrm{n}$. sp.); probably also reported in the NE Atlantic (Biarritz, SE France) with $R$. bouilleana A. Milne Edwards, 1872.

Description: as for type species.

Discussion: we justify the description of the new genus, in having a unique combination of distinctive characters within the Ranininae, different from the other genera ascribed to the subfamily, as follows:

- Lophoranina Fabiani, 1910, has distinct carapace surface with typical transverse tegulate rims, usually parallel to one other, two anterolateral spines bifid, broad sternum with $\mathrm{C}$-shaped concave lateral margins. 
- Lophoraninella Glaessner, 1936, has carapace with short scabrous ornamentation in anterior third, serrate transverse rimmed ornamentation on remainder of carapace.

- Ranina Lamarck, 1801, has triangular rostrum, smaller orbital spines, two anterolateral palmate spines that are respectively bifid or trifid in mature individuals, both anterolaterally directed, broad sternum at level of sternites 1-3.

- Raninella A. Milne Edwards, 1862, has carapace widest about half the distance posteriorly, carapace surface covered by densely spaced inclined nodes, anterolateral margin generally with two flattened spines triangular or more narrow, sternum lanceolate distally, narrow anteriorly and wider at level of the last posterior sternites.

- Remyranina Schweitzer \& Feldmann, 2010, has expanded, moderately broad fronto-orbital margin, ovoid carapace slightly larger than wide, and carapace ornamentation granular in anterior half and strongly terraced in posterior half.

- Vegaranina Van Bakel, Guinot, Artal, Fraaije \& Jagt, 2012, has anterolateral margin with three triangular spines, carapace ornamented with developed broadly spaced transverse terraces.

For detailed diagnosis see Karasawa et al. (2014).

\section{Alcespina ovadaensis $\mathrm{n} . \mathrm{sp}$}

Figs. 2-7

Ranina (Ranina) speciosa (von Münster, 1840) - Allasinaz 1987: 529-535, Pl.1, figs.11-16, Pl. 2, figs. 1-6, Pl. 3 , figs. 1-8.

?Ranina speciosa - Pasini \& Garassino 2017: 57-59, Fig. 12.

Diagnosis: as for the genus.

Etymology: the trivial name alludes to Ovada, close to which the fossiliferous sites are located.

Holotype: MPOM 290.

Paratypes:MPOM701,1770,1776,1779, 1780,17MT.

Examined material and measurements: MPOM 4, $5,10,11,13,20,21,23,171,288,290,701,1770,1776$, 1779, 1780, C1, C3, RMT, 17MT, 39C, from different localities of the Ligure Piemontese Basin. In the complete specimens, Ctw ranges between $44 \mathrm{~mm}$ to $56 \mathrm{~mm}$; Ctl ranges between $45.5 \mathrm{~mm}$ to $70 \mathrm{~mm}$.

Geological age: late Rupelian (early Oligocene).

Type locality: Galanti (Cassinelle, Alessandria, Piedmont, NW Italy).

Description: Allasinaz (1987) reported several specimens originally assigned to Ranina (Ranina) speciosa (von Münster, 1840). The original description in Italian language has never been translated. In this study we provide an updated description based upon the direct close review of the sample reported by Allasinaz (1987).

More (male) or less (female) ovate carapace slightly convex, longer than wide, tapering posteriorly, with maximum widest posteriorly to the base of the second anterolateral spine; wide orbito-frontal margin; frontal region, orbital, and anterolateral spines with marked sparse small pits, becoming smaller on the postfrontal regions; median and posterior re- gions with spiny tubercles frontally directed (Fig. 2). Convex front wide; trifid rostrum depressed medially, bounded on either bottom side by symmetrical lateral divergent triangular rostral teeth serving as inner-orbital spines (Fig. 2). Wide orbital margins with two teeth divided by two deep slightly divergent fissures; supraorbital tooth flat, forward directed with subtriangular anterior margin; postorbital tooth longer and larger, with three alternate points rounded distally; convex anterolateral margin, with two flat developed anterolateral spines; first anterolateral spine frontally directed and bifid, posterior margin slightly convex; second anterolateral spine wider and longer than the first one, elk horn-like shaped; upper margin nearly straight, strongly outward directed at an about $90^{\circ}$ angle to the carapace middle line, tapering to a blunt point and with three (occasionally a fourth spine is present) triangular smaller, serrate and unequal pointed spines on the upper margin, more or less slender and elongate (Fig. 2A); carapace dorsal regions indistinct; weak or obsolete branchiocardiac grooves concave longitudinally C-shaped; posterolateral margins slightly convex, tapering posteriorly and with a thin ridge; nearly straight posterior margin. Sexual dimorphism present, with a wider carapace inflated anteriorly and anterolateral spines wider and longer in mature adult males, above all the first one, forward projected at level of the rostrum and orbital spines, forming an apparently nearly straight frontal outline margin (Fig. 3A, B). Sparse punctate, broad sternum winged; sternites 1-3 reduced, fused and domed frontally; sternite 4 lateral margins concave, laterally expanded and convex on the anterior margin; sternite 5 with a medial longitudinal depression; triangular in outline and narrowing posteriorly (Figs. 3C, 4A). Pleonal six somites sparsely granulate, rounded in female; s1-s5 similar in thickness, decreasing in wideness posteriorly, inflated longitudinally, forming a middle blunt rounded carena marked by two parallel lateral depressions; s1-s5 with pleurae rounded distally; convex dorsal margin, concave posteriorly, tapering gently distally to the narrow s6; pleon subtriangular shaped in male, with first somite subtrapezoidal, wider than others and narrowing to s6 (Fig. 4C). Elongate subrectangular, narrow oxystomatous $3^{\text {rd }}$ maxilliped nearly complete, preserving articulate exo- and endopodite. Endopodite nearly twice longer than exopodite (Fig. 4B). Chelae subtriangular wider distally, with teeth similar in shape and size; very flattened transversely high palm, granulated dorsally, with outer side having transverse sinuous subparallel wrinkled rims; palm proportionally larger than long in adult male; dorsal margin of the palm with a strong distal forward pointed spine near the articulation with the dactylus; lower margin of the palm bearing five alternate and pointed triangular spines saw-teeth like shaped forward directed, decreasing in size posteriorly; the anterior first longer; dactylus pointed, tip strongly curved downward, straight occlusal margin armed with a serrate rim of short teeth; triangular wide straight index, transverse to the axis of the palm, downward directed, armed with a rim of same size alternate teeth; reduced triangular carpus ending with two distal spines, ornamented with smooth transverse subparallel rims on the outer side; merus subtriangular, longer than carpus with a spine frontally directed on the outer margin; prominent scale lines at the mid dorsal outer side (Fig. 5A-C); ambulatory legs poorly preserved, flattened laterally, distal dactyli not preserved. 

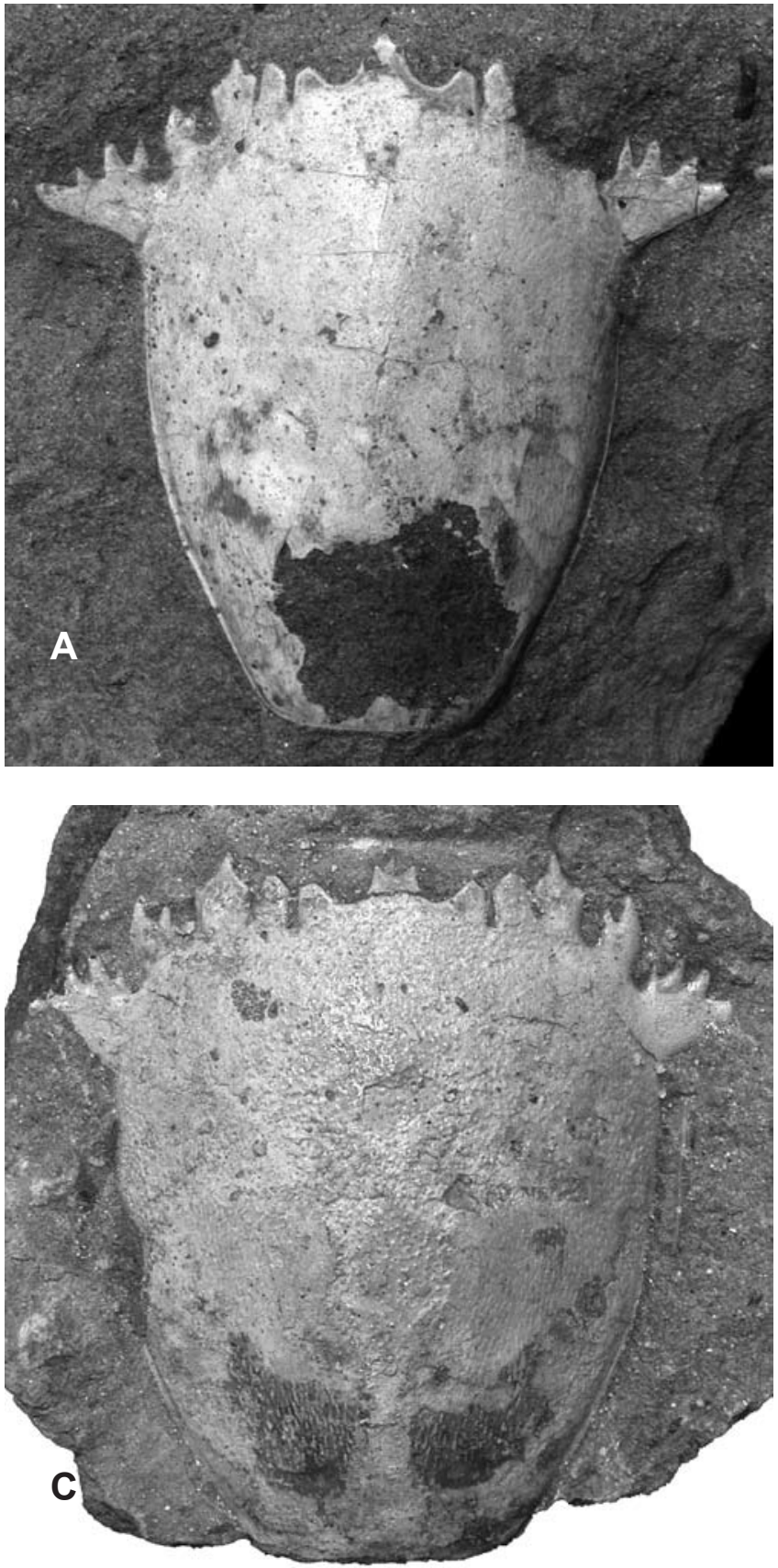
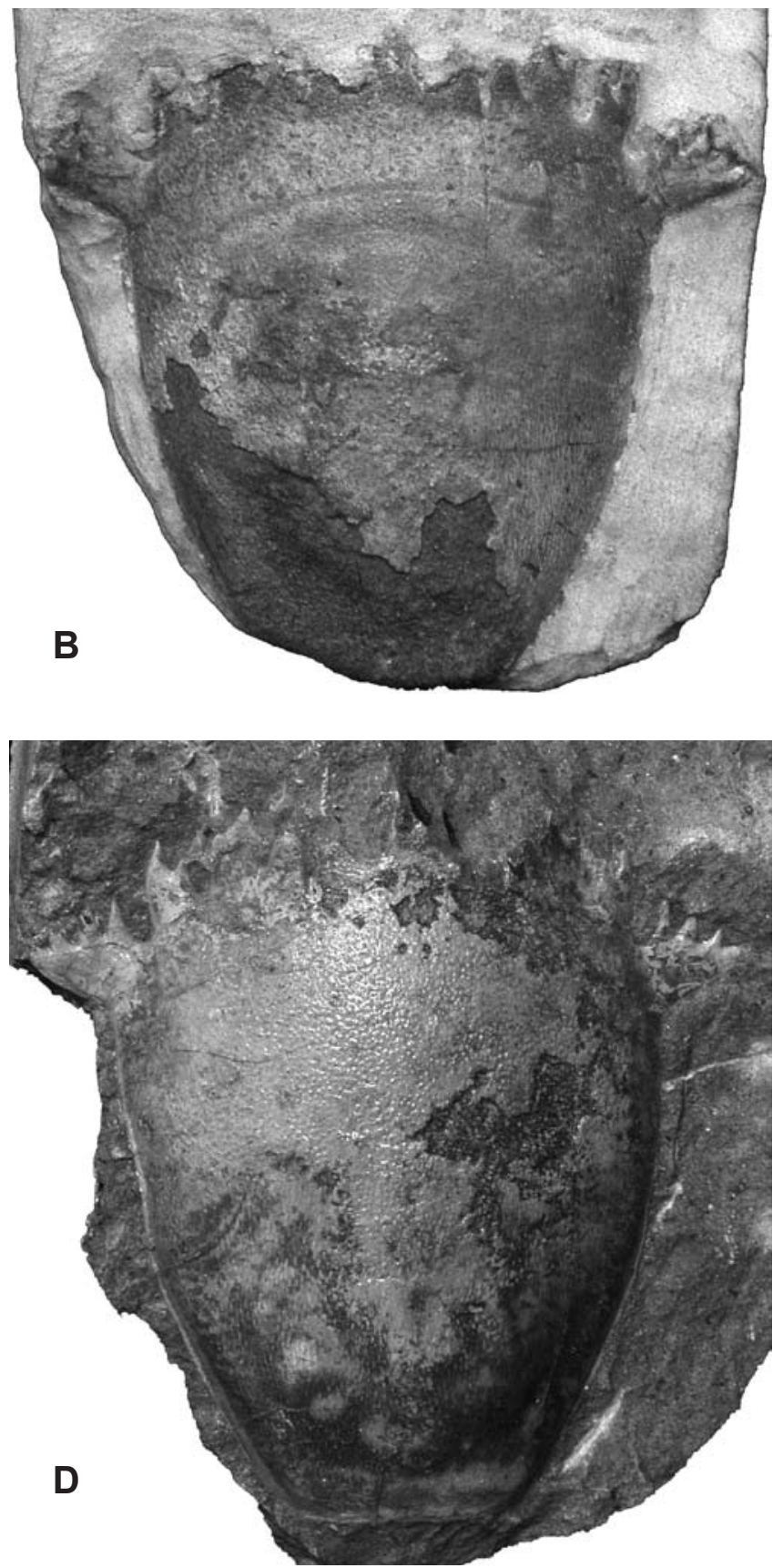

Fig. 2 - Alcespina ovadaensis n. gen., n. sp., carapace in dorsal view. A) holotype, MPOM 290 (Galanti, Cassinelle) (x 1.6). B) paratype, 17MT (Rio Volpina, Ponzone) (x 1.4). C) paratype, MPOM 1770 (Ciglione) (x 1.4) . D) paratype, MPOM 1779 (Ponzone) (x 1.5).

Intraspecific variability. The availability of a rich sample of specimens at different stages of growth, sizes, and preservation, allows us to point out the possible range of intraspecific variability in the main 'proxy characters' sensu Schweitzer (2003). The carapace shape changes proportionally in outline, more or less elongate or inflate anteriorly, with the ornamentation of the dorsal exoskeleton variable in size and arrangement, with more or less sparse granulations and distribution of the pits, based on the individual size and sex, but always well distinct between the postfrontal and the dorsal-posterior regions. The rostrum is always distinctly trifid in all individual stages. The width of the anterolateral spines may be individually more or less marked, with the first always bifid with the inner spine more or less developed and pointed, frontally directed, whereas the second one may have 3 to 4 accessory spines on the upper margin, alternate or adjacent, pointed, thin, and elongate or shorter triangular, and flat (Fig. 6). Tip of the second spine pointed or blunt, always strongly outward directed, pointed or smooth nearly perpendicular to the carapace midline. The first anterolateral spine in larger mature males is strongly developed frontally and flattened, proportionally longer than the second anterolateral spine. Moreover, the P1 chelae are distinctly wider than long in mature larger specimens. 

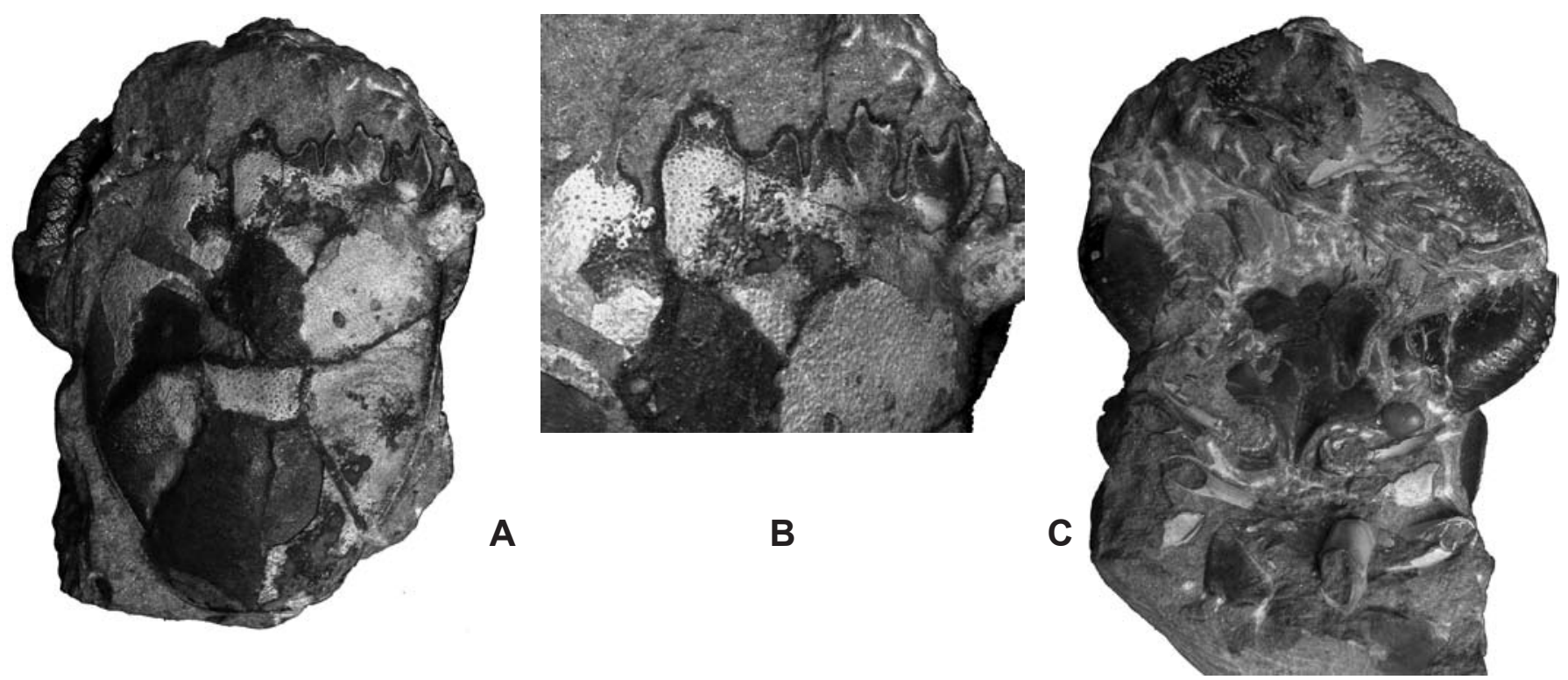

Fig. 3 - Alcespina ovadaensis n. gen., n. sp, MPOM 1780 (Ciglione), mature male. A) dorsal view (natural size). B) anterolateral outline (x 1). C) pleonal view (x 1.1).

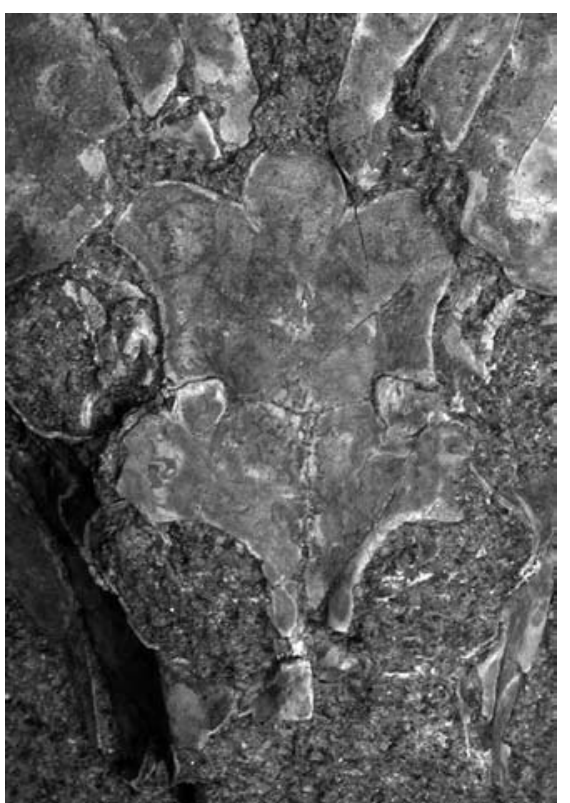

A

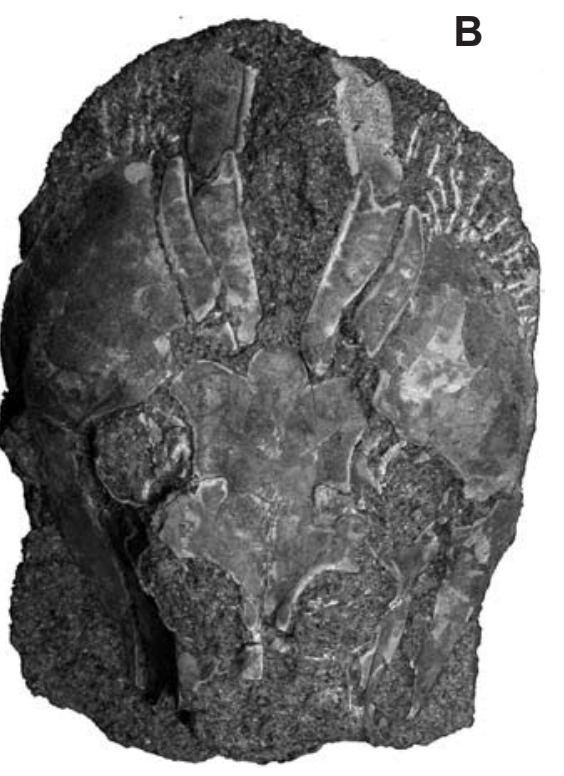

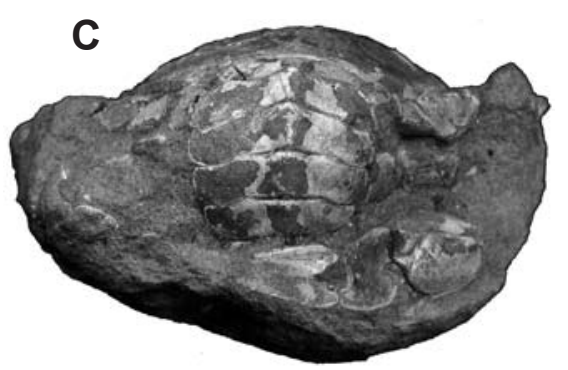

Fig. 4 - Alcespina ovadaensis n. gen., n. s.p., RMT (Giusvalla). A) ?female sternum (x1.8). B) $3^{\text {rd }}$ maxilliped with endo- and exopodites (x 1.1). C) MPOM 39 (Ciglione), female somites (natural size).

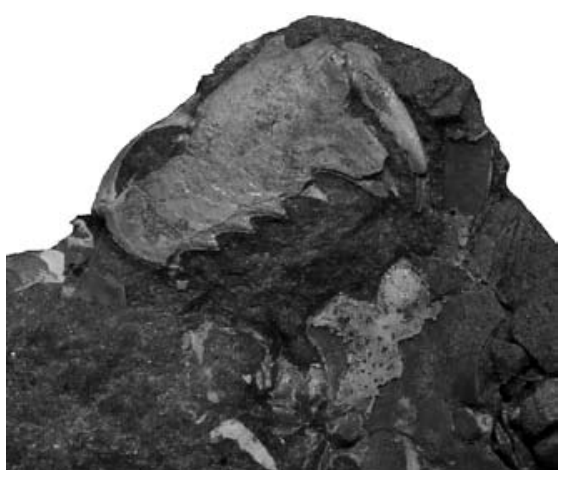

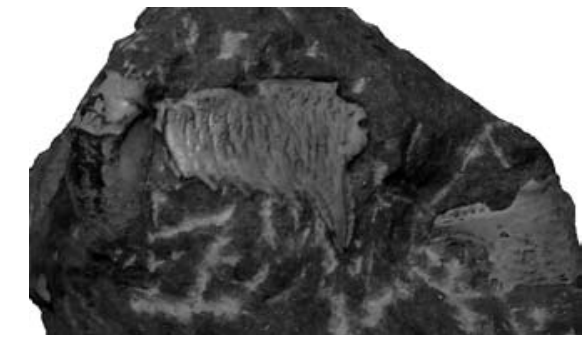

A

B

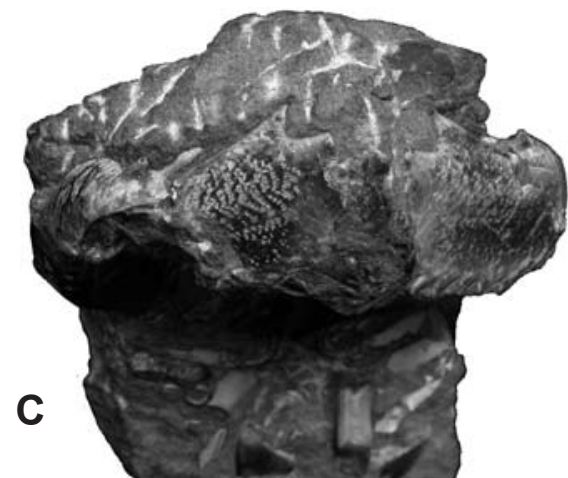

Fig. 5 - Alcespina ovadaensis n. gen., n. sp. A) C3 (Ponzone), right chela (x 1.3). B) MPOM 740 (Ciglione), right and partial left chela (natural size). C) MPOM 1780, male chelae (x1.1). 

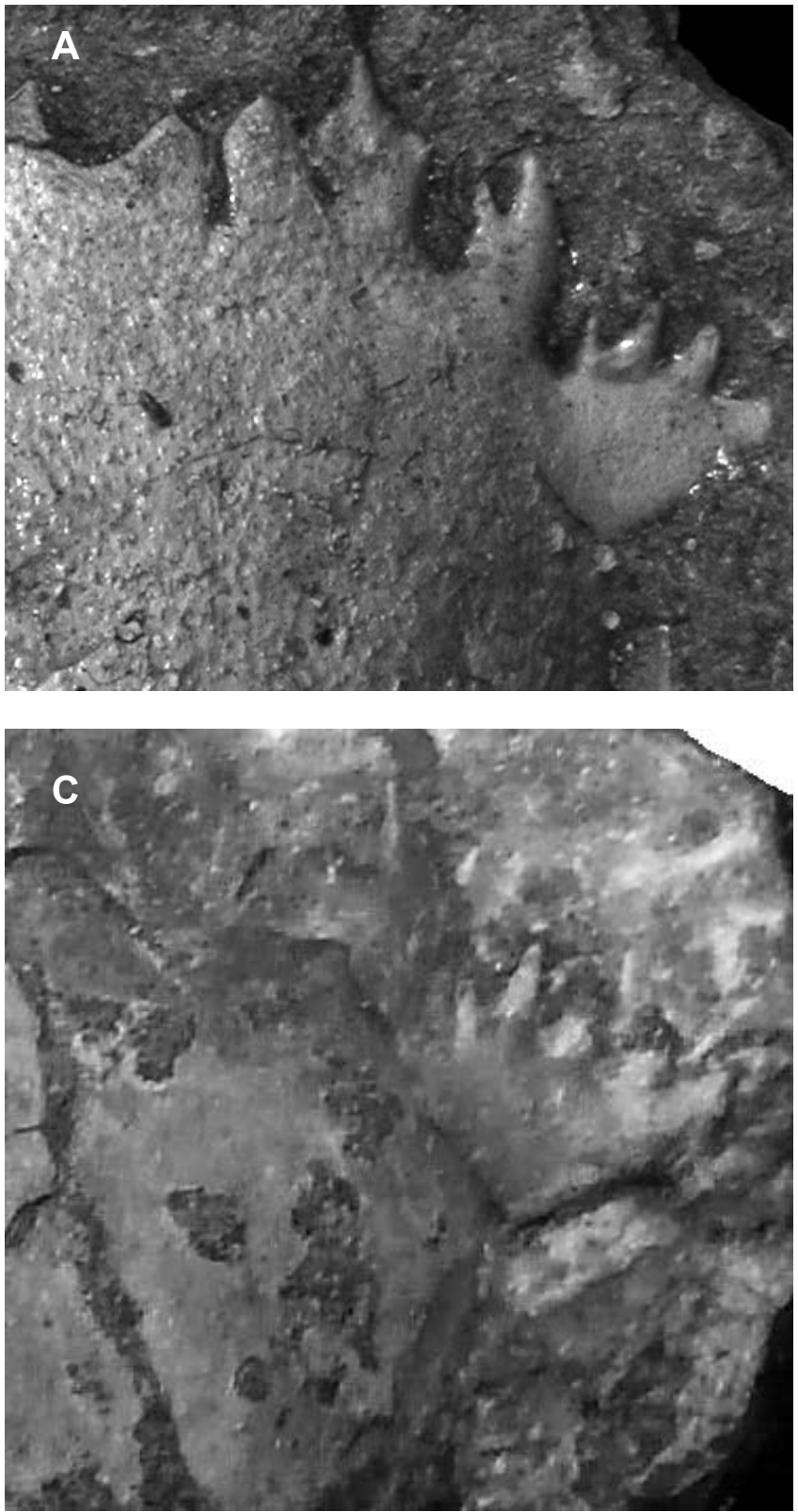
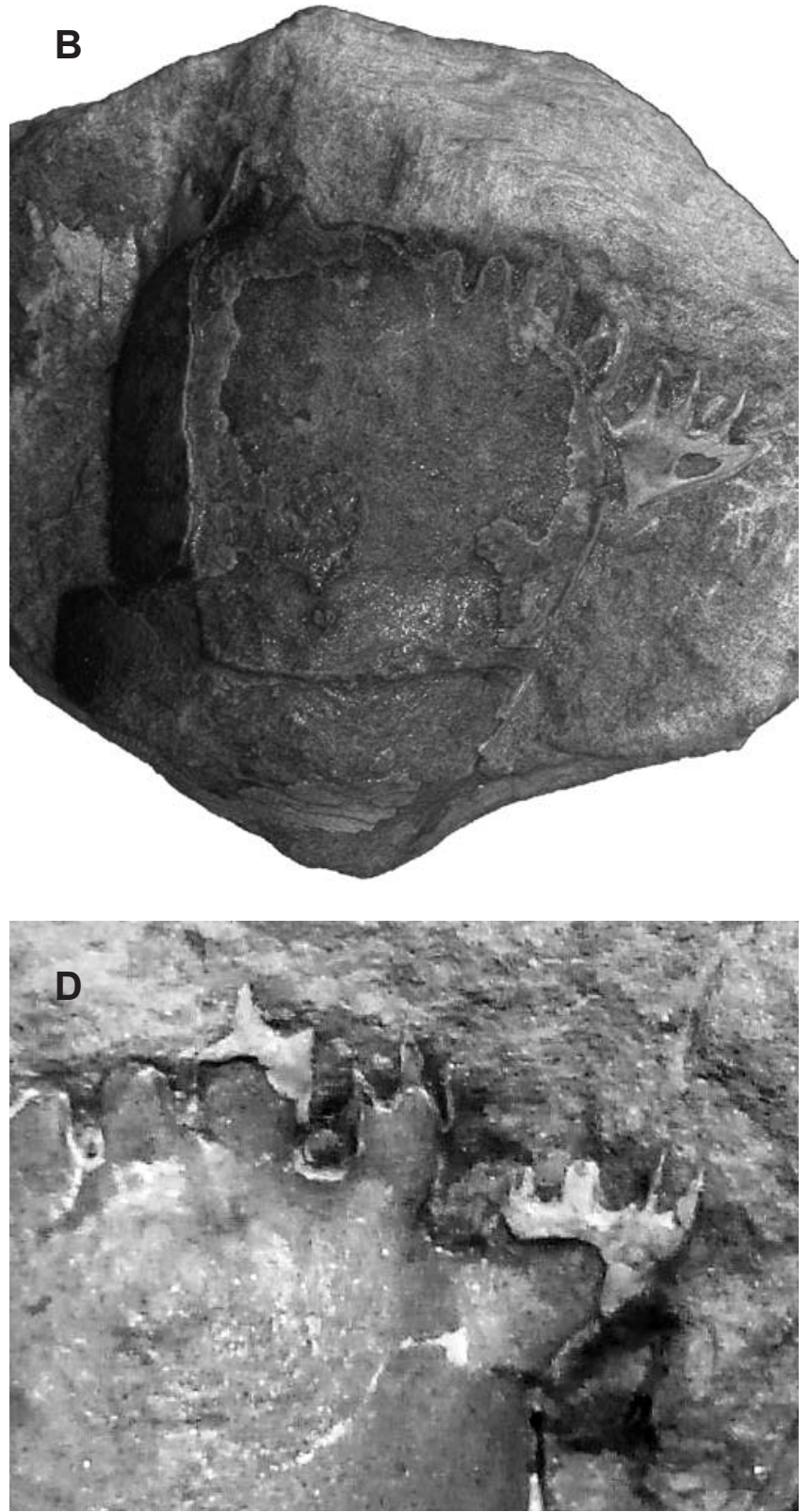

Fig. 6 - Alcespina ovadaensis n. gen., n. sp., variability in the $2^{\text {nd }}$ anterolateral spine. A) MPOM 1770 (x 2.5). B) MPOM 23 (x 1.7). C) MPOM 701 (x 2.2). D) MPOM 1776 (x 2.5).

Note. Two poorly preserved specimens (MNHM R03540, same catalog number for both specimens), from Western Atlantic of the early Oligocene of Biarritz (SW France) previously assigned to Ranina bouilleana, still considered as a doubtful species (see discussion in Pasini \& Garassino, 2017: 48) might also be assigned to $\mathrm{Al}$ cespina n. gen., in having a bifid first anterolateral spine frontally directed and outward strongly directed second anterolateral serrate spine, but different dorsal ornamentation on the postfrontal region of the carapace as to $A$. ovadaensis n. gen., n. sp. Unfortunately, the poor preservation of both specimens, lacking the rostrum and complete frontal margin, does not allow the assignment within this genus (Fig. 7).

Finally, five small carapaces, collected from the Rigoroso Marl layers of several localities of the Ligure-
Piemontese Basin and considered by Allasinaz (1987: 533, tab. 1, figs. 12-16-51M, 137M, 139M, MPOM 248, MPOM 288) as molting of juvenile individuals of Ranina (Ranina) speciosa , "... also if their morphological characters remember those of Raninella" have been herein re-examined. These specimens, preserved as internal moulds, have a: slender, convex and nearly smooth carapace that is longer than wide with a middle longitudinal smooth carina; convex frontal margin flattened with triangular elongate pointed rostrum depressed medially; wide supraorbital margin marked by two deep oblique fissures and frontal spines developed; and one anterolateral triangular spine fronto-laterally directed. These are typical morphological characters of Raninoides. Two specimens (MPOM 288 and 137M) display some specific diagnostic characters, such as: a short preor- 
bital tooth; a supraorbital triangular tooth narrower and longer than the preorbital tooth; extraorbital teeth directed forward; and the presence of a proximal postfrontal punctate ridge slightly convex anteriorly running between the reduced anterolateral pointed spines. The above-

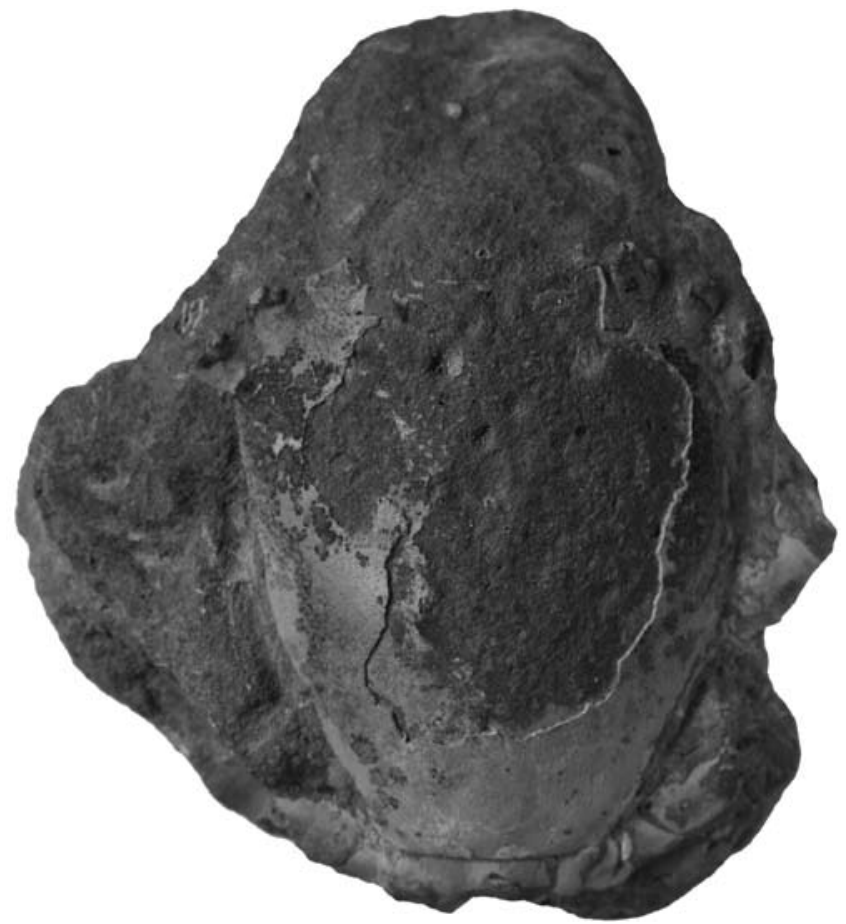

mentioned characters closely resemble Raninoides pliocenicus De Angeli, Garassino \& Pasini, 2009. Therefore the five studied specimens are compared to Raninoides cf. $R$. pliocenicus (Raninidae De Haan, 1839) despite the notable different geological age (Fig. 8).

Fig. 7 - ?Ranina bouilleana A. Milne Edwards, 1872. MNHN R03540 (x 0.9).
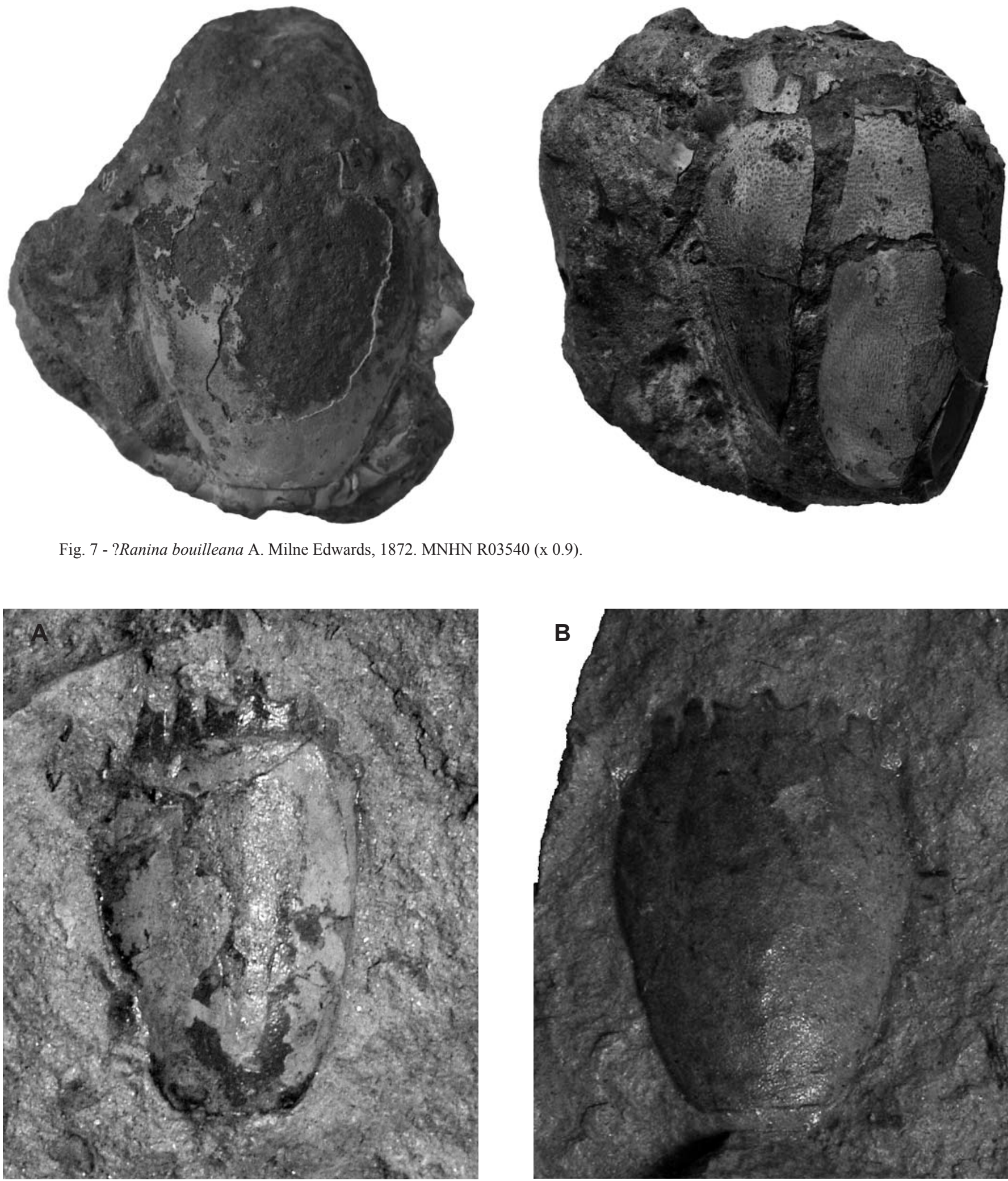

Fig. 8 - Raninoides cf. R. pliocenicus De Angeli, Garassino \& Pasini, 2009 (Ciglione): A) MPOM 288 (x 4.6). B) 137M (x 4.1). 
Alcespina berglundi (Squires \& Demetrion, 1992) n. comb.

Figs. 10, 11

Ranina berglundi Squires \& Demetrion, 1992; 43, 44, figs. $128,129$.

Ranina berglundi - Vega et al. 2001: 929. - Schweitzer et al. 2006: 27-29, Figs. 2.5, 2.6. - Vega et al. 2008: 54, Pl. 1, figs. 13-15; P1. 2, figs. 1, 2. - Schweitzer et al. 2010: 74. - De Angeli \& Beschin 2011: 13. - Van Bakel et al. 2012: 208 .

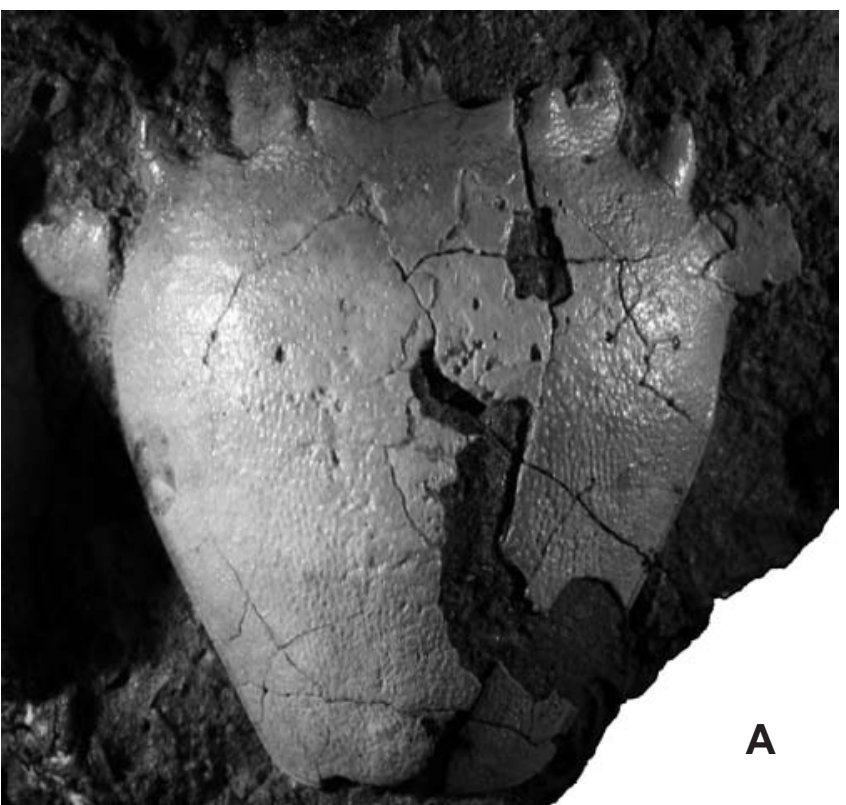

?Ranina berglundi - Pasini \& Garassino 2017: 46, 47, Fig. 2.

Holotype: IGM 5913.

Paratype: IGM 5914.

Examined material and measurements: holotype and paratype by original figures (Squires \& Demetrion, 1992: figs. 128, 129); MHN-UABCS/Ba 7-3; fig. 2, 5 and MHN-UABCS/Ba 10-10; fig. 2, 6 from the Bateque Fm., Baja California Sur, Mexico (Schweizer et al., 2006: 28).

IGM 5913 - Ctw: $39 \mathrm{~mm}$; Ctl: $38 \mathrm{~mm}$.

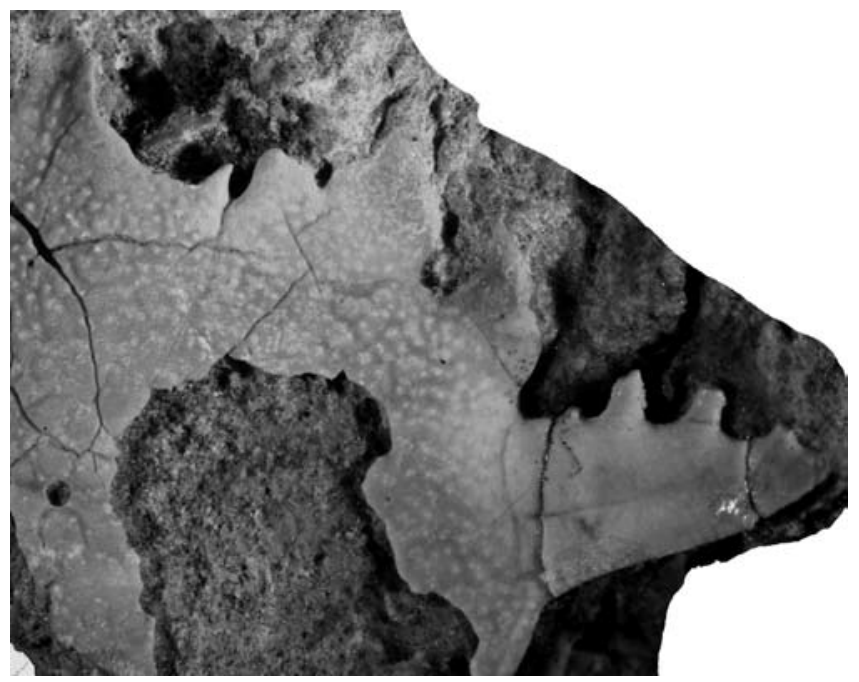

B

Fig. 9 - Alcespina berglundi (Squires \& Demetrion, 1992) n. comb. A) holotype, IGM 5913 (x 1.8). B) paratype, IGM 5914 (x 4.5).
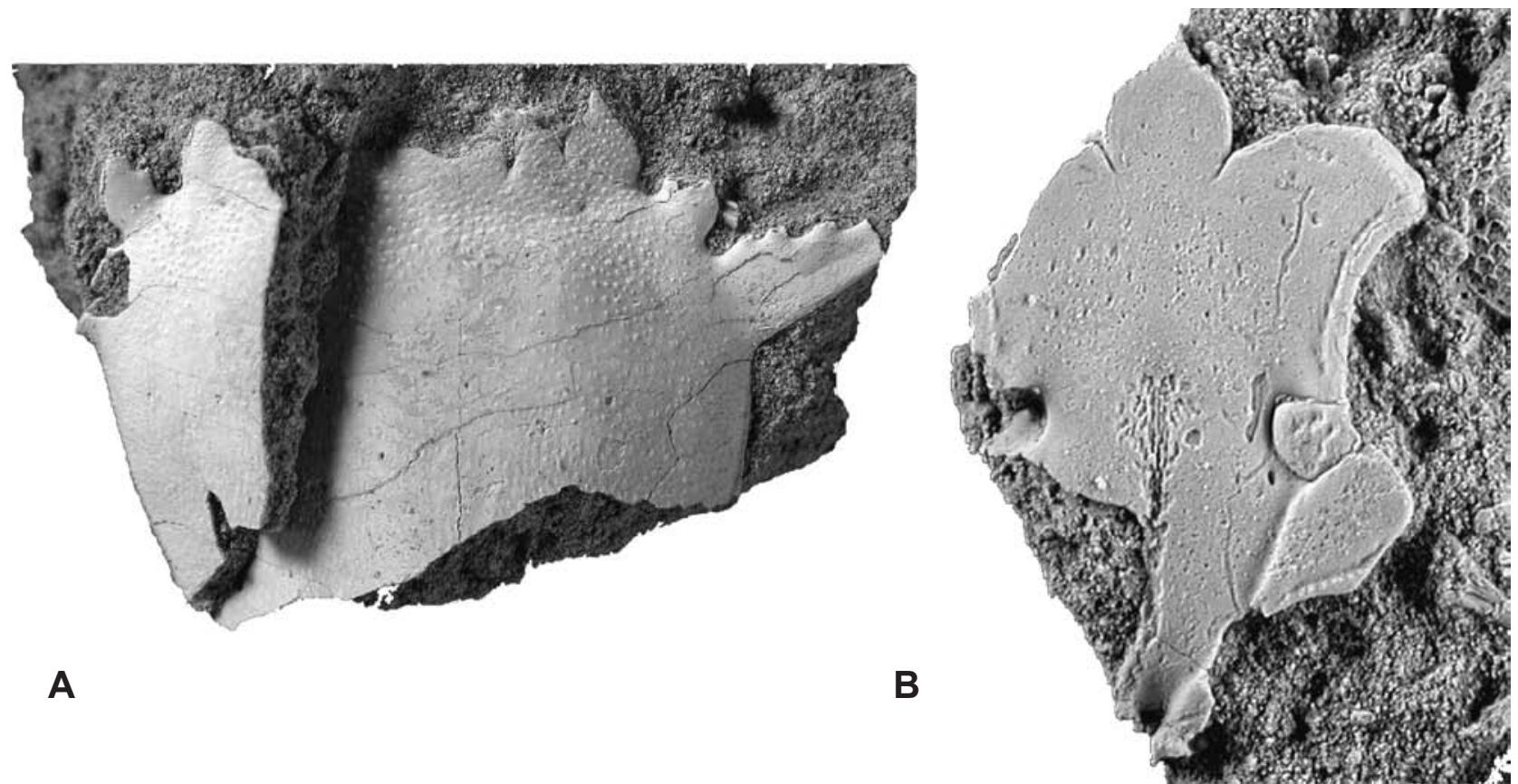

Fig. 10 - Alcespina cf. A. berglundi (Squires \& Demetrion, 1992). A) partial carapace, MHN-UABCS/Ba 7-3 (x 1.5). B) sternum, MHN-UABCS/Ba 10-10 (x 1.5). 
Geological age: early Eocene.

Type locality: CSUN 1220b; Baja California Sur, (Mexico), Bateque Formation.

Original diagnosis by Squires \& Demetrion (1992): a Ranina s.s. with a wide fronto-orbital margin, two equally spaced wide and strong anterolateral spines (outermost one serrate), and wide spacing between all spines.

Emended diagnosis (present study): carapace ovate, wide orbito-frontal margin convex; trifid pointed rostrum, depressed medially; first anterolateral spine bifid, forward directed, parallel to the middle longitudinal axis; second wider anterolateral spine pointed, flat, nearly straight upper margin outward directed, forming a strong angle $\left(75^{\circ}\right.$ or more) to the carapace middle line, with four unequal serrate spines on the upper margin.

Description: Ranina berglundi Squires \& Demetrion, 1992, was described based upon four specimens from the early Eocene of Baja California Sur (Mexico), having a scarcely elongate carapace and "...small pits sparse on the anterior middle part, closer posteriorly and toward lateral and anterior borders. ...outer orbital spine triangular. ... triangular first anterolateral spine pointed ..., second anterolateral spine, ...extended at a 45-degree angle (note: along the posterior margin of the spine) to a blunt spine, with four serrations on anterior edge of spine ... carapace dorsal surface covered by small nodes in pits, distributed randomly on upper two thirds of carapace, aligned in rows on posterior portion..." (Squires \& Demetrion, 1992: 44). The paratype (IGM 5914), though incomplete, shows some characters, such as the wide frontal margin, the trifid sulcate rostrum, the first anterolateral spine frontally directed and bifid, the second anterolateral spine wider, flat strongly outward directed (forming an about $75^{\circ}$ angle to the carapace middle line), with unequal four spines on upper straight margin, that fit with those of Alcespina n. gen. (Fig. 9).

Schweitzer et al. (2006), reported also six specimens referred to $R$. berglundi, collected from the Bateque Fm., Mexico "at localities different from those collected by Squires \& Demetrion (1992) in the same unit". Among these specimens one dorsal partial carapace (MHN-UAB$\mathrm{CS} / \mathrm{Ba}$ 7-3; Fig. 10A) preserves both the anterolateral spines, showing instead first spine bifid than "triangular" and "pointed", as in the original description by Squires \& Demetrion (1992). Only the second anterolateral spine is slightly less outward directed than in the type material. The postfrontal ornamentation consists in distinct sparse pits, whereas the middle and posterior carapace regions are not preserved. Schweitzer et al. (2006: 28), attributed a portion of a poorly preserved sternum (not preserved in the type material from Baja California Sur), to $R$. berglundi: "....sternites 1-3 fused, sternite 4 broad, anterior margins convex, lateral margins concave, sternite 5 poorly known, with shallow longitudinal depression." (MHN-UABCS/Ba 10-10; Fig. 10B). Also these poorly preserved specimens could be prudentially compared to A. berglundi n. comb.

Moreover, Vega et al. (2008: Pl.1, figs. 13-14; Pl. 2, fig.1) reported three specimens from the early Eocene, El Bosque Formations (Chiapas, Mexico) ascribed to Ranina berglundi. These specimens, having "small difference in the size and distribution of the dorsal pits" (Vega et al., 2008: 54), cannot be ascribed to Ranina berglundi for the outline of the carapace, the stronger ornamentation, the deeply impressed gastro-cardiac grooves. Unfortunately the frontal region and the first anterolateral spine are poorly preserved, making difficult the systematic assignment of the Chiapas specimens. However we point out that just the specimen IHNFG-3015 (Vega et al., 2008: Pl. 2, fig. 1) preserves the first anterolateral bifid spine and the second anterolateral spine having shape and direction similar to that of Alcispina n. gen.

Based upon the original specimens of $R$. berglundi and the specimens discussed herein we warrant placement of $R$. berglundi within Alcespina n. gen. As stated above $R a-$ nina differs notably from Alcespina $\mathrm{n}$. gen. in having a peculiar triangular rostrum, quite different shape and direction of both anterolateral spines, and different sternum outline. Therefore Alcespina berglundi (Squires \& Demetrion, 1992) n. comb. is herein designated.

Finally, A. berglundi n. comb. differs from the type species $A$. ovadaensis n. gen., n. sp., in having: smaller size, less elongate subovate carapace; a dorsal ornamentation, with coarse more marked pits on the postfrontal regions and shorter coarse spines/tubercles on the remainder of the carapace; a second anterolateral spine less outward directed (the medial axis forming an about $75^{\circ}$ angle to the longitudinal carapace middle line), with four unequal spines on the anterior edge of the spine. At present, $A$. berglundi n. comb. represents the oldest representative for the genus having an exclusive Eastern Pacific distribution.

\section{CONCLUSIONS}

The critical review of the Ranininae fossil specimens from the late Oligocene of Ligure Piemontese Basin, allows identification and description of the new genus Alcespina, with $A$. ovadaensis n. gen., n. sp., as type species.

At the same time Ranina berglundi, is assigned to Alcespina with $A$. berglundi (Squires \& Demetrion, 1992) n. comb., based on the distinctive morphological characters of the new genus. Moreover, $A$. berglundi represents the oldest representative for the genus known to date, having its possible origin in the central eastern Pacific Ocean, with probable migration to the western Atlantic coasts and Tethys during the early-late Eocene, following some dispersal migratory oceanic route from West to East (for example see Schweitzer et al., 2002). Moreover we point out that the specimen from the late Eocene of Hoko River Formation (Washington, USA) previously assigned to $R$. americana by Karasawa et al. (2014: 35, Fig. 18C; KSU D677) having outward strongly directed second anterolateral serrate spine, might be assigned to Alcespina n. gen., after a close revision of this questionable specimen.

Finally, the Italian Oligocene small sized specimens previously assigned to Ranina speciosa are herein assigned to Raninoides cf. R. pliocenicus De Angeli, Garassino $\&$ Pasini, 2009, representing the older record for this Mediterranean species. 


\section{Acknowledgements}

We thank Piero Damarco, Museo Paleontologico "G. Maini" of Ovada, Alessandria (Italy), who allowed us the study of the type series and assisted us by sedimentological and geological information and by detailed photos of the most singinficant specimens. Moreover, we thank Francisco J. Vega, Istituto de Geología, UNAM, Coyocán, (Mexico), for additional pictures and useful discussion on the type material of Ranina berglundi. Finally we thank Francisco J. Vega, Istituto de Geología, UNAM, Coyocán, (Mexico) and Torrey Nyborg, Department of Earth and Biological Sciences, Loma Linda University, Loma Linda, CA (USA) for criticism and review.

\section{REFERENCES}

Allasinaz A., 1987 - Brachyura, Decapoda oligocenici (Rupeliano) del Bacino Ligure Piemontese. Bollettino del Museo Regionale di Scienze naturali di Torino, 5 (2): 509-566.

De Angeli A. \& Beschin C., 2011 - Il genere Ranina Lamarck, 1801 (Crustacea, Decapoda, Raninidae) nel Terziario del Vicentino, con descrizione di due nuove specie. Studi e Ricerche - Associazione Amici del Museo - Museo Civico “G. Zannato”, 18: 11-20.

Karasawa H., Schweitzer C.E., Feldmann R.M. \& Luque J., 2014 - Phylogeny and classification of Raninoida (Decapoda: Brachyura). Journal of Crustacean Biology, 34 (2): 216-272.

Pasini G. \& Garassino A., 2017 - A preliminary review of the fossil species of Ranina Lamarck, 1801 (Decapoda, Brachyura, Raninidae), with systematic remarks. Natural History Sciences Atti della Società italiana di Scienze naturali e del Museo civico di Storia naturale in Milano, 4 (1): 43-72. doi: 10.4081/nhs.2017.310

Ristori G., 1889 - Crostacei piemontesi del Miocene inferiore. Bollettino della Società Geologica Italiana, 7 : 397-413.

Schweitzer C.E., 2003 - Utility of proxy characters for classification of fossils: an example from the fossil Xanthoidea (Crustacea: Decapoda: Brachyura). Journal of Paleontology, 77 (6): 1107-1128.

Schweitzer C.E., Feldmann R.M., Garassino A., Karasawa H. \& Schweigert G., 2010 - Systematic list of fossil decapod crustacean species. Crustaceana Monographs, 10: 1-222.

Schweitzer C.E., Feldmann R.M., González-Barba G. \& Cosovic V., 2006 - New Decapoda (Anomura, Brachuyra) from the Eocene Bateque and Tepetate Formations, Baja California Sur, Mexico. Bulletin of the Mizunami Fossil Museum, 33: 21-45.

Schweitzer C.E., Feldmann R.M., Gonzales-Barba G. \& Vega F.J., 2002 - New crabs from the Eocene and Oligocene of Baja California Sur, Mexico and an assessment of the evolutionary and paleobiogeographic implications of Mexican fossil decapods. Paleontological Society Memoir, 76: 1-43.

Squires R.L. \& Demetrion R.A., 1992 - Paleontology of the Eocene Bateque Formation, Baja California Sur, Mexico. Natural History Museum of Los Angeles County Contributions in Science, 434: 1-55.
Van Bakel B.W.M., Guinot D., Artal P., Fraaije R.H.B. \& Jagt J.W.M., 2012 - A revision of the Palaeocorystoidea and the phylogeny of raninoidian crabs (Crustacea, Decapoda, Brachyura, Podotremata). Zootaxa, 3215: 1-216.

Vega F.J., Cosma T., Coutiño M.A., Feldmann R.M., Nyborg T.G., Schweitzer C.E. \& Waugh D.A., 2001 - New Middle Eocene decapods (Crustacea) from Chiapas, México. Journal of Paleontology, 75 (5): 929-946.

Vega F.J., Nyborg T., Coutiño M.A. \& Hernández-Monzón O., 2008 - Review and additions to the Eocene decapod Crustacea from Chiapas, Mexico. Bulletin of the Mizunami Fossil Museum, 34: 51-71. 